\title{
The Burden of a Family in Caring For Members Who Suffer From Mental Disorders
}

\author{
$1^{\text {st }}$ Sri Martini \\ Nursing Department \\ Poltekkes Kemenkes Palembang \\ Palembang, Indonesia \\ srimartini@poltekkespalembang.ac.id \\ 3rd Yunike \\ Nursing Department \\ Poltekkes Kemenkes Palembang \\ Palembang, Indonesia \\ yunike@poltekkespalembang.ac.id
}

\author{
$2^{\text {nd }}$ Ira Kusumawaty \\ Nursing Department \\ Poltekkes Kemenkes Palembang \\ Palembang,Indonesia \\ irakusumawaty@poltekkespalembang.ac.id \\ $4^{\text {th }}$ Detiana \\ Nursing Department \\ Poltekkes Kemenkes Palembang \\ Palembang,Indonesia \\ detiana@poltekkespalembang.ac.id
}

Corresponding author: yunike@ poltekkespalembang.ac.id

\begin{abstract}
Changes and advancement of people daily living haveextremely complex consequences, thereby constructive adaptation processes are necessary in dealing with it. However, not all individuals have the ability to constructively adapt to a change so that it can ultimately cause mental disorders. Exploration of the family burden as a support system for the patients is very important because of the high dependence of the patients to their family in dealing with the disease. Even though it is also a responsibility for the family members to be concernedof the patients condition. This study aims to explore the burdenof a family in caring for a family member who is mentally disturbed. A phenomenological approach was applied in this qualitative research. In-depth interviews were concluded after obtaining data saturation. Data saturation was acquired after interviewing 5 families of patients. Data analysis conducted using the Collaizi method which resulted in four themes, namely: The burden experienced since the beginning of patients 'caring, raging emotions as $\mathbf{n}$ negative yet hidden impact of caring, the economic problems due to costs needed to treat the patients and the feeling of failure in caring which disrupt the treatment progress. It was concluded that treating mentally disordered patients could also burden the families, notably the psychology aspect. Therefore the cooperation of the family is a crucial matter to provide in caring for the sufferers.
\end{abstract}

Keywords: family burden, caregiver, mental disorder, caring.

\section{INTRODUCTION}

Changes in environmental and social conditions have a wide impact on a person's mental state in which the consequences are very complex. When a person is unable to deal with complex changes in a short time, it can result in disruption of psychological conditions. The distortion that occurs disrupts the fulfillment of the needs of daily life [1]. Schizophrenia is suspected to be the most common psychiatric disorder and can cause many disorders. Disorders that occur provide a heavy burden that is complicated, for patients who are also felt by the family [2]. However, there is a feeling of being burdened bythe presence of a family member of the sufferer so that it might be able to contribute to the willingness, willingness and sincerity of the family while caring for the sufferer [3]. There are many matters which bring up the feeling of being. overwhelmed when a family member must accompany the sufferer while undergoing treatment. In general, at the beginning of being diagnosed with a mental disorder, the family feels taken aback, confused, concerned and don't know what they should do. But this is not the case when thefamily has been caring for a long time. The longer you treat the patient, the tiresome it feels because the improvement orchange in the patient's condition does not appear in a short time. 
The slow process of recovering a patient's condition worsens and aggravates the burden on the family as a caregiver [4], [5], [6]. It takes a long time to be able to see changes in the condition of the patient's behavior. Improving the condition of patients with very minimal does not have asignificant positive impact in reducing family burden [7], [8], [6].

\section{METHODS}

A qualitative descriptive method was applied in this study with a phenomenological approach. This research was carried out in a public health center working area located in the provincial capital and has implemented a mental health service program. The caregiver who became a participant was a family caregiver whose family members had been diagnosed with a mental disorder and had been treated at a mental hospital. After the in- depth interview process and considering data saturation, the number of participants was 7 people

The research was carried out in the working area of one public health center with the most mental disorders in Palembang. The data collection process was carried out by researchers through in-depth interviews, with interviews lasting around 30-45 minutes held at the patient's home as many as 2-3 meetings. The timing of the interview was agreed based on discussion with the participants. The form of data collection instruments used in this study uses a semi-structured in-depth interview guide developed by the researcher by referring to the literature review. In addition, researchers use voice recording aids to record sounds and cellphones to document the research process. Before the interview was conducted, the researcher made a draft interview in the form of an interview sheet. Interview sheets are prepared based on theories relevant to the problem in the study. Questions are open, not rigid, because the questions can develop according to the process that takes place during the interview without leaving the theoretical basis established in the study. Questions raised during indepth interviews are in-depth interview guidelines developed to explore the burden of the family as a caregiver for a family member suffering from a mental disorder. Each question raised is a question that can be developed in accordance with the conditions and responses of participants when interviewed. Researchers still pay attention so that the questions asked must remain based on the research concept.
The questions asked include:

1. What is the experience when caring for family members who have mental disorders?

2. During treating patients, what problems does the family face?

3. How is family acceptance of sufferers?

4. How can you survive while caring for sufferers?

5. What is the burden on the family as a caregiver when caring for sufferers?

6. What is the support of other family members for the care provided?

7. What is the form of family coping in dealing with problems while caring?

Before the interview begins, participants receive an explanation of informed consent so that they know the purpose of the study and the importance of their role as participants. After they stated their understanding of the informed consent that was explained by the researcher, the participants then signed the informed consent sheet. Data from the results of in-depth interviews are directly outlined in the form of interview transcripts, not waiting for the in-depth interview process to be completed as a whole. Thus, the interview process is carried out simultaneously with the process of preparing the transcript. Researchers read the transcript repeatedly, to identify the meaning and achievement of the saturation of information that has been obtained. The analysis process was carried out in conjunction with the preparation of the transcript, however in general the stages traversed following the Collaizi model were as follows: making transcripts, reading transcript scripts repeatedly, identifying significant statements, formulating keywords or coding each participant's phrase that was considered important, several related keywords are grouped into narrative forms to further describe them into several themes that are relevant to the purpose of the study.

Result

\section{RESULT}

Table 1 Description of familycharacteristics

\begin{tabular}{ccccccc}
\hline $\begin{array}{c}\text { No } \\
.\end{array}$ & $\begin{array}{c}\text { Participant } \\
\text { characterist } \\
\text { ics }\end{array}$ & $\begin{array}{c}\text { Partici } \\
\text { pant A }\end{array}$ & $\begin{array}{c}\text { Partici } \\
\text { pant B }\end{array}$ & $\begin{array}{c}\text { Partici } \\
\text { pant C }\end{array}$ & $\begin{array}{c}\text { Partici } \\
\text { pant D }\end{array}$ & $\begin{array}{c}\text { Partici } \\
\text { pant E }\end{array}$ \\
\hline 1. & $\begin{array}{c}\text { Age } \\
\text { (years old) }\end{array}$ & 35 & 35 & 42 & 50 & 42 \\
\hline 2. & Sex & Female & Female & Female & Male & Female \\
\hline 3. & Profession & $\begin{array}{c}\text { Washing } \\
\text { laborers }\end{array}$ & $\begin{array}{c}\text { House } \\
\text { wife }\end{array}$ & $\begin{array}{c}\text { Food } \\
\text { vendors }\end{array}$ & $\begin{array}{c}\text { Street } \\
\text { vendors }\end{array}$ & $\begin{array}{c}\text { Washing } \\
\text { laborers }\end{array}$ \\
\hline & $\begin{array}{c}\text { Relationship } \\
\text { with sufferers }\end{array}$ & Mother & Wife & Mother & Husband & Sister \\
\hline 5. & $\begin{array}{c}\text { Duration of } \\
\text { caring (years) }\end{array}$ & 5 & 7 & 2 & 2 & 4 \\
\hline
\end{tabular}


The following is the theme presented based on the results of in- depth interview analysis through coding instructions.

1. Theme: The burden felt since the beginning of the treatment process.

The first theme is supported by some coding: Felt as a 5 . heavy burden

Feeling unable to start Unable to start in caring

More severe than physical illness.

Interview quote: When he heard he was sick at the beginning, O God ... what is wrong ... it's hard to feel this.

It used to be that I was unable to take care of him, confused about what to do with my younger brother, went awry, asked a lot, asked here.

First of all, it doesn't feel good, It's hard, caring for him can't be taken lightly, it's harder than caring for someone who is physically ill.

2. Theme: Raging emotions as an impact of having the burden of caring.

Coding:

Psychologically tired Fed up

Sad, sorry, upset

Interview quote: I don't know, it feels hard to nurture him, while he is healthy, briefly recurs, he feels tiring.

It's not tired if you treat him bad, but tired, unclear condition, easy to change.

If it's good, it's really good.

But if you don't want to talk, it's hard to communicate. Tired of this heart, feelings of sadness, pity, annoyance is also there when taking care of my sister.

3. Theme: The economic problems due to the costs needed to treat the patients.

Coding:

It costs a lot Low income

Postpone to check to the doctor

Interview quote: If you want to take him to the hospital, it's far, it costs a lot too.

I'm just a washing laborer, my salary is not enough, if you go to the hospital for a fare, it's not enough fifty thousand, at least you have to bring 100,000. Even though my salary is 250 thousand a month.

Sometimes I only visit the doctor at the hospital when I have enough money, if I don't then I have to postpone it.

4. Theme: accept the destiny reluctantly. Coding: God's Provisions

Accepted as God's destiny Sometimes there is a denial of destiny
Interview quote: Maybe God has predestined me to care for him.

I believe in God's destiny, but why should I have a problem like this, it's hard.

I accept all of this, I accept, but I am tired and tired of enduring conditions like this.

If it wasn't me who had problems like this, I don't know if it felt strong enough to bear this destiny.

5. Theme: Feelings of failure in caring which disrupt the treatment progress.

Coding: Feeling unable to care. Misunderstandings often occur

Feeling unsuccessful in taking care of the patient. Interview quote: I was unable to care for my brother, it was difficult to care for him.

If I have much money, then it's better to pay someone else, because I have tried to take care him myself, but I can't. It often leads to misunderstanding.

I really could not take care of him, really difficult, because I could not mind him. It is really difficult because I could not read his mind. It is different with treating a cold or fever. They were easy, the pain will not take a long time to heal, it's easy to cure. While mental illness is not clear when it will health, it makes me feel that I will not be able to take care of him.

\section{DISCUSSION}

Based on this study, the results show that the age of caregiver schizophrenic patients is in the age range of 20-50 years, female. Specifically, it consists of 5 people who are the patient's mother and 2 people are the patient's sister. The caregiver's job is as a washing laborer, street vendor, Pedi cab driver or motorboat driver. Previous research states that the majority of caregivers are female, as happened in Japan and Taiwan[9]. Caregiver age is mostly in adulthood (2050 years). In Iran the caregiver age is 15-64 year. Most of those who provide treatment are sufferers. As one research shows that in general family members who care for sufferers are sufferers [10].

The burden felt since the beginning of patients' treatment. In general, families say that the burden of caring for sufferers is felt from the first time a sufferer is diagnosed with a mental disorder. As research states the same thing that families feel a burden that is very heavy and difficult to forget when the first time a family member is disrupted psychological condition [11], [4]. Even the family complains that not all family members are willing to treat patients, this can be caused by busyness or ignorance in caring, thus aggravating the burden felt by family members who must be responsible for caring for the sick. 
Raging emotions as an impact of having the burden of caring. Taking care a mental disorder patient is a home care that takes a long time. When treatment at home has been undertaken by sufferers, then of course it must be continued with recovery care at home the presence of this patient can have an impact on the condition at home [11]. Psychologically, the presence of sufferers can present anxiety, fear towards other family members, patients can be considered as components that burden the family [12]. Changes in the patient's condition suddenly cannot be denied a cause of chaos in the family and often caregivers do not understand how to provide understanding to patients [1] as happened in the study this, the family does not understand how to care for the family when the patient does not want to interact or communicate with the caregiver.

The economic problems due to costs needed to treat the patients. By looking at the age of caregiver, it appears that the caregiver is in the productive age, so that there is a demand for them to care to have an impact on the reduction in working time, thereby reducing the income they should. Especially if the caregiver is the backbone for the family, this condition can disrupt the economy in the family. One of the results of this study revealed that economic factors also became a problem in treating sufferers who were mentally disturbed [13]. Notably in this study, patients mostly come from low income families by working as a street vendor, Pedi cab driver, water boat driver and even washing laborer. Poverty is a determinant component in the worsening condition of sufferers, because of the powerlessness to reach health services [14]. The higher the income of the family's economy, the better the decisions will be taken by the family to come to the health services, as well as visiting mental health services. Decision taken by the family is very determining factor of the improvement of the patient's condition, given the time recovery of the patient's psychological condition requires a very long span of time, even the process takes a lifetime the quality of caring for the family of a sick family member.

Accept the destiny reluctantly. Acceptance of destiny emerged as one of the themes of the research results. This can be explained as a family coping effort in calming him so that he is more able to accept reality. As research which revealed that in general the sufferer's family accepts the presence and special condition of the sufferer as a destiny that cannot be denied [15], [16]. This happens when the family has been treating patients for a long time, so that the process of accepting patients is gradually increasing along with family efforts to find out about how to treat patients. Various exposure to suffering, difficulties, challenges, ridicule makes the family increasingly looking for solutions to suffer the problems of sufferers, although on the other hand it adds even more burden to the family. The time needed by the family to pay attention to sufferers is not insignificant, in addition to the need for physical presence of the family to always accompany the sufferer [17].

Feelings of failure in caring which disrupt the treatment progress. The feeling of failure often surrounds families who have to care for sufferers. Feelings of inadequacy, failure and fatigue in caring for years sometimes weaken the strength of the family. The progress of mental disorder patient condition happen slowly. Something similar happened to the results of the study which explained the severity of the failure felt by the caregiver while taking care of the patients [18]. Sudden changes of the patient's condition adds to the complexity of the family while caring for the patient can behave cooperatively during the treatment. The increasing complexity of the patient's problem worsens the feeling of failure experienced by the family.

\section{CONCLUSION}

Based on the results of the study it can be concluded that there is a burden felt by the family of the mental disorder patients threlated to his psychology condition. The family should be ready and enduring in facing the burden. Support from other family members needs to be shown to caregiver families so that the burden will be feel lighter than it seems.

\section{ACKNOWLEDGMENT}

Thank you to Health Polytechnic of Palembang for the opportunity and support given to the implementation of this research.

\section{REFERENCES}

[1] Barbeito S, Teresa S, Becerra-Garc Ja, Gonz A. Journal PreProof 2019. Https://Doi.Org/10.1016/J.Jad.2019.11.106.

[2] Niman S. Pengalaman Family Caregiver Dalam Merawat Anggota The Phenomenon Of Family Caregiver Experience In Caring For Families With Mental Disorders 2019.

[3] Rhee Tg, Rosenheck Ra. Does Improvement In Symptoms And Quality Of Life In Chronic Schizophrenia Reduce Family Caregiver Burden? Psychiatry Res 2019;271:402-4. Https://Doi.Org/10.1016/J.Psychres.2018.12.005.

[4] Avasthi A. Preserve And Strengthen Family To Promote Mental Health. Indian J Psychiatry 2010;52:113-26. Https://Doi.Org/10.4103/0019-5545.64582.

[5] Kusumawaty I, Yunike Y, Pastari M. Penyegaran Kader Kesehatan Jiwa Mengenai Deteksi Dini Gangguan Jiwa Dan Cara Merawat Penderita Gangguan Jiwa. J Community Engagem Heal 2020;3:25-8. Https://Doi.Org/10.30994/Jceh.V3i1.27. 
[6] Kusumawaty I. Pendampingan Psikoedukasi: Penguatan Caring Oleh Caregiver Keluarga Terhadap Orang Dengan Gangguan Jiwa. J Med (Media Inf Kesehatan) 2020;7:8390. Https://Doi.Org/10.36743/Medikes.V7i1.206.

[7] Chadda Rk. Caring For The Family Caregivers Of Persons With Mental Illness 2014;56:221-7. Https://Doi.Org/10.4103/0019- 5545.140616.

[8] Kusumawaty I, Yunike, Podojoyo. The Complexity Of Caring For People With Mental Disorders: Family Challenges In Contributing To Horticultural Therapy. Pakistan J Med Heal Sci 2020;14:1442-6.

[9] Chang Kh, Horrocks S. Lived Experiences Of Family Caregivers Of Mentally Ill Relatives 2006:435-43.

[10] Geriani D, Satish K, Savithry B. Burden Of Care On Caregivers Of Schizophrenia Patients: A Correlation To Personality And Coping

[11] Gross Jj, Uusberg H, Uusberg A. Mental Illness And WellBeing: An Affect Regulation Perspective 2019:130-9. Https://Doi.Org/10.1002/Wps.20618.

[12] Ljungqvist I, Topor A, Forssell H, Svensson I. Money And Mental Illness : A Study Of The Relationship Between Poverty And Serious Psychological Problems. Community Ment Health J 2015. Https://Doi.Org/10.1007/S10597-015-9950-9.

[13] Navab E, Negarandeh R, Peyrovi H. Lived Experiences Of Iranian Family Member Caregivers Of Persons With Alzheimer 'S Disease : Caring As ' Captured In The Whirlpool Of Time' 2012:1078-86. Https://Doi.Org/10.1111/J.13652702.2011.03960.X

[14] Stuart H. Reducing The Stigma Of Mental Illness. Lancet 2001;357:1055. Https://Doi.Org/10.1016/S01406736(00)04269-0.

[15] Noguchi M, Tachimori H, Naganuma Y, Zhao X, Kono T, Horii S. Families' Opinions About Caring For Patients With Psychiatric Disorders After Involuntary Hospitalization In Japan 2016. Https://Doi.Org/10.1177/0020764015614595.

[16] Lúcia A, Souza R, Guimarães Ra, Vilela Dda, Assis Rm De, Malagoni L, Et Al. Factors Associated With The Burden Of Family Caregivers Of Patients With Mental Disorders: A Cross-Sectional Study 2017:1- 10. Https://Doi.Org/10.1186/S12888-017-1501-1.

[17] Dalky Hf. Perception And Coping With Stigma Of Mental Illness: Arab Families' Perspectives. Issues Ment Health Nurs 2012;33:486Https://Doi.Org/10.3109/01612840.2012.676720.

[18] Wilton Rd, Ph D. Poverty And Mental Health: A Qualitative Study Of Residential Care Facility Tenants 2003;39:139-56. 